Article

\title{
Fatigue Behavior of Cold-Worked High-Interstitial Steels
}

\author{
Sedat Güler and Alfons Fischer * (D) \\ Materials Science and Engineering, University of Duisburg Essen, 47057 Duisburg, Germany; \\ sedat.gueler@uni-due.de \\ * Correspondence: alfons.fischer@uni-due.de; Tel.: +49-203-379-4372
}

Received: 8 May 2018; Accepted: 7 June 2018; Published: 11 June 2018

\begin{abstract}
The austenitic high-nitrogen (AHNS) and high-interstitial steels (AHIS) with more than 0.6 weight- $\% \mathrm{~N}$ allow for a yield strength above $1.1 \mathrm{GPa}$ and a tensile strength above $1.5 \mathrm{GPa}$ by maintaining an elongation to fracture markedly above $30 \%$. These steels gain their prominent mechanical properties from the fact that at the chosen sum of $\mathrm{C}+\mathrm{N}$ and $\mathrm{C} / \mathrm{N}$-ratios, the concentration of free electrons is higher compared to that of other steels. Thus, the capacity to dissipate plastic work under monotonic tensile loading is unique. Now, the fatigue limit of austenitic steels in general is mainly governed by the sum of interstitials and should be further improved by cold working. Unfortunately, this is not the case for the AHNS and AHIS and is in contrast to the classical CrNiC- or $\mathrm{CrMnC}$-steels. Thus, tensile and fatigue tests of cold-worked samples were conducted and analyzed by scanning- and transmission-electron microscopy. This paper tries to elucidate the metallurgical reasons, as well as the material engineering aspects, of such peculiar behavior of AHNS and AHIS.
\end{abstract}

Keywords: fatigue; high-interstitial steels; persistent Lueders bands

\section{Introduction}

The development of austenitic high-Nitrogen steels (AHNS) has allowed for the further improvement of a combination of strength and ductility [1]. Beside the corrosion resistance, the high content of $\mathrm{N}$ in solid solution has also improved the endurance limit [2-5]. One limitation has resulted from the fact that the AHNS required a special production route to keep $\mathrm{N}$ in solution, which made them inappropriate for casting and many welding technologies. In order to overcome these limitations, $\mathrm{N}$ was partly substituted by $\mathrm{C}$ and the so-called austenitic high-interstitial steels (AHIS) were developed [6-9]. But, despite the fact that cold-working of these CrMn-steels increased the yield and tensile strengths drastically by maintaining a marked elongation to fracture, the endurance limit did not follow this trend, as was expected from austenitic CrNi-ones with and without N [10-12]. The reasons for this were attributed to the difference in sliding characteristics of such steels, which, besides $\mathrm{N}$, are mainly governed by the amount of $\mathrm{Ni}[13,14]$. CrNiCN steels show wavy slip under fatigue, while the higher the $\mathrm{N}$-content up to 0.4 weight- $\%$, the more planar slip takes place. Still, the wavy slip fraction rules the cyclic properties, e.g., under reciprocating sliding wear [15]. In contrast, the Ni-free CrMnCN steels always and solely showed planar slip [6-8,16]. The AHIS even revealed a better endurance in rotating bending tests in the solutions annealed state, as well as after $20 \%$ cold-working [17].

The question that appeared related to which metallurgical features rule the slip behavior under fatigue. The stacking fault energy (SFE) alone does not explain this, because it is in the range of austenitic CrNi-steels [9,18-23]. Another strong factor for wavy or planar slip is the density of free electrons $\mathrm{D}_{\mathrm{F}}$, as has been shown for, e.g., Cu-alloys [24]. But, these are substitutional solid solutions for which the combination of SFE and $D_{F}$ governs the slip characteristics. For interstitial solid solutions 
like in AHNS, a strong Mo-N interaction has been discussed [25]. However, this would not apply for the Mo-free AHIS. Another and maybe even more distinct problem that needs to be addressed to understand this peculiar behavior arises from the fact that all investigated austenitic $\mathrm{CrNiC}_{-}, \mathrm{CrNiCN}-$, and $\mathrm{CrMnCN}$-steels show very little dislocation activities at the endurance limit and if at all, they can be attributed to planar slip [13]. This is why most fatigue papers about slip characteristics use finite life tests with distinct plastic strain amplitudes that allow for crack initiation. Finally, any work-hardening method might have an influence as well. While [26] used rod-drawn blanks with a typical deformation gradient over the cross section, the blanks in [17] were elongated in order to gain a homogenous deformation grade within the entire volume.

Thus, and on the basis that all austenitic steels show planar slip at the endurance limit, we concluded in [13] that it is not the planar or wavy slip characteristics that govern the fatigue limit, but that it is just the general tendency of such steels to either planar or wavy slip. The question arose whether this tendency to a lesser homogenous distribution of strains within the microstructure is also the reason why, after cold work, the fatigue limit does not follow about $\frac{1}{2}$ of $\mathrm{R}_{\mathrm{p} 0.2}$ for AHNS and AHIS, while it does for austenitic $\mathrm{CrNiC}$-steels.

Thus, solution annealed samples (one AHNS and three AHIS) were uniaxially strain hardened at $35 \%$ and $40 \%$, respectively, which is well below uniform strain but above the $20 \%$ of [17]. Afterwards, the cold-worked specimens were tested by means of a strain-controlled axial fatigue tests in the finite and infinite life regime. In this contribution, the endurance limit is described and compared to that of CrNi-steels.

\section{Materials and Methods}

\subsection{Investigated Steels}

Table 1 lists the chemical compositions of the steels investigated. 1.4452 is a commercially available austenitic high-Nitrogen steel (AHNS), while the CN-grades represent so-called austenitic high-interstitial steels (AHIS) for their lower N/C-ratios [1,9].

Table 1. Chemical composition in weight- $\%$ of investigated steels.

\begin{tabular}{ccccc}
\hline Steel & $\mathbf{1 . 4 4 5 2}$ & CN0.85 & CN0.96 & CN1.07 \\
\hline Designation & CrMnMoCN0.95 & CrMnCN0.85 & CrMnCN0.96 & CrMnCN1.07 \\
\hline $\mathrm{C}$ & 0.08 & 0.26 & 0.34 & 0.49 \\
$\mathrm{Cr}$ & 18.00 & 18.26 & 18.20 & 18.82 \\
$\mathrm{Fe}$ & bal. & bal. & bal. & bal. \\
$\mathrm{Mn}$ & 14.00 & 18.52 & 18.89 & 18.88 \\
$\mathrm{Mo}$ & 3.50 & 0.04 & 0.06 & 0.07 \\
$\mathrm{~N}$ & 0.88 & 0.59 & 0.61 & 0.58 \\
$\mathrm{Ni}$ & 0.12 & 0.26 & 0.34 & 0.41 \\
$\mathrm{Si}$ & 1.12 & 0.26 & 0.3 & 0.43 \\
$\mathrm{C}+\mathrm{N}$ & 0.95 & 0.85 & 0.96 & 1.07 \\
$\mathrm{~N} / \mathrm{C}$ & 11.67 & 2.27 & 1.78 & 1.18 \\
\hline
\end{tabular}

All steels were first solution-annealed at $1150{ }^{\circ} \mathrm{C}$ for 45 to $60 \mathrm{~min}$ and quenched. Cone-head samples were manufactured from $\varnothing 20 \times 100 \mathrm{~mm}$ blanks and afterwards ground and polished within the reduced length of $28 \mathrm{~mm}$ (Figure 1). Grinding was carried out in the axial direction by means of SiC-emery paper (Struers, Willich, Germany) down to a 1200 mesh size, followed by polishing with either polycrystalline diamond (ATM GmbH, Memmelzen, Germany) of a $1 \mu \mathrm{m}$ grain size or electrochemically in perchloric acid $(700 \mathrm{~mL}$ ethanol, $110 \mathrm{~mL}$ aqua dest., $100 \mathrm{~mL}$ Butyldiglycol, $78 \mathrm{~mL}$ perchloric acid) at $-35^{\circ} \mathrm{C}$. Finally, the specimens were inspected by means of a light microscope at five-fold magnification in order to check for surface flaws. 


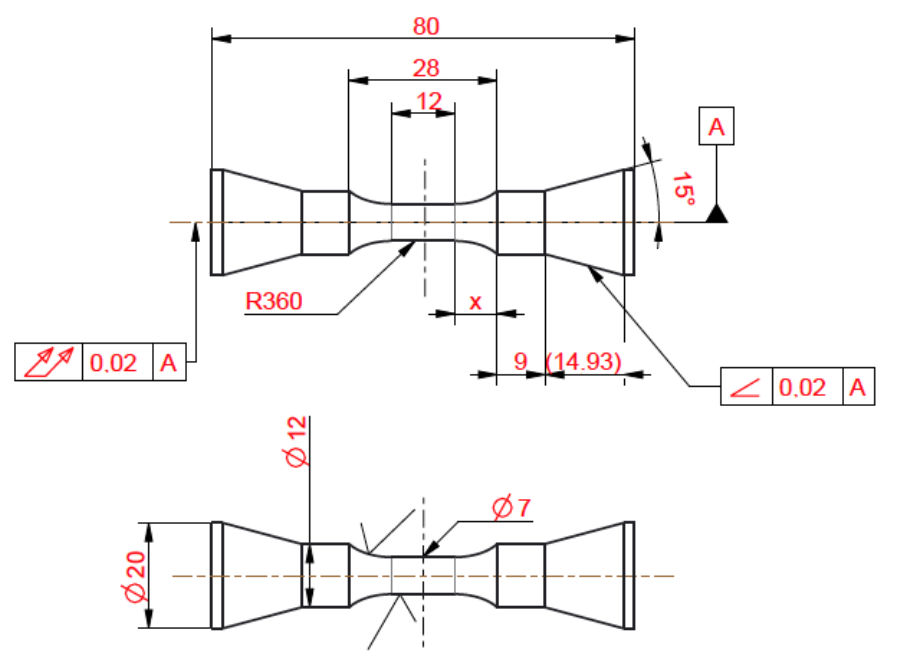

Figure 1. Specimens for tensile tests and uniaxial fatigue tests; all numbers in $\mathrm{mm}$.

Afterwards, eleven samples of each steel were uniaxially strained by means of a tensile test rig up to $35 \%$ and $40 \%$, respectively. This was followed by tensile tests of three of these samples in order to gain the respective properties for the cold-worked state.

\subsection{Fatigue Tests}

Total strain-controlled fatigue tests in the range of $0.1 \% \leq \varepsilon_{\mathrm{a}, \mathrm{t}} \leq 3 \%$ (total strain amplitude) were conducted with a constant strain rate of $4 \times 10^{-3} \mathrm{~s}^{-1}$ and at a strain ratio $\mathrm{R}_{\varepsilon}=\varepsilon_{\mathrm{a}, \mathrm{t} \text { min }} / \varepsilon_{\mathrm{a}, \mathrm{t} \cdot \max }=-1$ by means of a servohydraulic test rig (Bionix 858, MTS, Berlin, Germany and Extensometer 632.13F-20, MTS, Berlin, Germany). In order to avoid any thermal heating of the specimens, the test frequencies of sine-wave loading were chosen to be $0.5 \mathrm{~Hz}$ for $\varepsilon_{\text {a.t }}>0.8 \%$ and at $2.5 \mathrm{~Hz}$ for $\varepsilon_{\text {a.t }}<0.8 \%$. All tests were run either up to $2 \times 10^{6}$ cycles $(\mathrm{N})$ or until fracture $\left(\mathrm{N}_{\mathrm{f}}\right)$. The measured stress-strain hystereses were further analyzed in terms of their elastic $\left(\varepsilon_{\mathrm{a}, \mathrm{e}}\right)$ and plastic $\left(\varepsilon_{\mathrm{a}, \mathrm{p}}\right)$ fractions according to the Ramberg-Osgood method described in [27]. The cyclic strain hardening exponent $\mathrm{n}^{\prime}$ and the cyclic strength coefficient $\mathrm{K}^{\prime}$ were derived at $\mathrm{N} / 2$ or $\mathrm{N}_{\mathrm{f}} / 2$, respectively. In parallel, Manson-Coffin-Basquin analyses were carried out in order to estimate the endurance limits on the basis of data from the finite and the infinite life regimes. Thus, the fatigue limits $\sigma_{\mathrm{D}}$ have been determined at $\mathrm{N}=2 \times 10^{6}$ according to the method for life time estimation, which considers the compatibility of Ramberg-Osgood and Manson-Coffin-Basquin parameters [28]. Further details can also be found in [29].

\subsection{Metallography and Microscopy}

Longitudinal cross sections before and after mechanical testing were prepared. After wet cutting (Accutom-50, Struers, Willich, Germany), the samples were embedded, ground, and polished. Grinding was carried out using abrasive SiC-paper down to a 1200 mesh size (Struers, Willich, Germany). Polishing was done down to a $1 \mu \mathrm{m}$ grain size polycrystalline diamond suspension (ATM GmbH, Memmelzen, Germany) for light optical microscopy (LOM) (Microscope: BX-10, Olympus, Düsseldorf, Germany; Camera: DFC 420, Leica, Heerbrugg, Switzerland; Documentation Software: ImageAccess Standard 7, Imagic Bildverarbeitung AG, Glattbrugg, Switzerland), followed by etching for HV10 hardness measurements. Alternatively, a $0.05 \mu \mathrm{m}$ colloidal silica suspension (Masterprep Polishing Suspension, Buehler, Düsseldorf, Germany), vibratory polishing (Vibromet, Buehler, Düsseldorf, Germany), and finally electro-polishing (LectroPol-5, Struers, Willich, Germany) were necessary for electron backscatter diffraction analyses (EBSD). LOM and scanning electron microscopy (SEM) were used for microstructural characterization before and after mechanical testing. SEM was performed using a LEO 1530 GEMINI (Carl Zeiss Microscopy GmbH, Munic, Germany) field emission gun 
supplemented with a combined microanalysis system (AMETEK_EDAX, Ametek GmbH, Wiesbaden, Germany) consisting of the Apollo X Silicon drift detector with TEAM 3.11 software (Ametek GmbH, Wiesbaden, Germany) for energy dispersive spectroscopy (EDS) and a Digiview IV CCD camera (Ametek GmbH, Wiesbaden, Germany) with OIM 6.2 data collection (Ametek GmbH, Wiesbaden, Germany) and analysis software for EBSD.

After fatigue tests, samples were also prepared for transmission-electron microscopical (TEM) analyses. Discs of a $0.5 \mathrm{~mm}$ thickness were wet-cut (Accutom-50, Struers, Willich, Germany) fixed to a holder and ground (Phoenix3000, Buehler, Ratingen, Germany) down to $70 \mu \mathrm{m}$ by means of SiC emery paper from a 320 to 1200 mesh size. This was followed by polishing (Rotopol 31, Struers, Willich, Germany) both sides with 6 to $1 \mu \mathrm{m}$ diamond suspension and finalized by polishing (OP-Chem+MasterMet2, Struers, Willich, Germany). Then, $3 \mathrm{~mm}$ discs were punched out mechanically and electrochemically thinned to $80 \mathrm{~nm}$ (Tenupol3+A2, Struers, Willich, Germany) [29]. TEM investigations were carried out by means of an EM400 (Phillips, Eindhoven The Netherlands) and a JEOL2200FS (Jeol Ltd., Tokyo, Japan).

\section{Results}

\subsection{Tensile Properties}

The mean tensile properties and their standard deviations of the solution annealed and the work-hardened samples are listed in Table 2 . As has been shown earlier by many authors $[1,9,10,30,31]$, such interstitially alloyed austenites reveal a marked strain hardening behavior by still preserving ductility. While the AHNS reaches a yield strength of nearly $1.9 \mathrm{GPa}$ after $40 \%$ cold-work, the AHIS $\mathrm{R}_{\mathrm{p} 0.2}$-values range from 1.3 to $1.5 \mathrm{GPa}$, which can be gradually ranked by the sum of $\mathrm{C}+\mathrm{N}$.

Table 2. Tensile properties of the investigated steels after solution annealing and after uniaxial cold-working.

\begin{tabular}{ccccc}
\hline Steel & $\mathbf{1 . 4 4 5 2}$ & CN0.85 & CN0.96 & CN1.07 \\
\hline Designation & CrMnMoCN0.95 & CrMnCN0.85 & CrMnCN0.96 & CrMnCN1.07 \\
\hline & \multicolumn{4}{c}{ Solution annealed [13] } \\
\hline Yield strength $\mathrm{R}_{\mathrm{p} 0.2 \text { in MPa }}$ & $631 \pm 13$ & $587 \pm 17$ & $595 \pm 9$ & $585 \pm 10$ \\
Tensile strength $\mathrm{R}_{\mathrm{m}}$ in MPa & $1022 \pm 23$ & $1000 \pm 14$ & $1027 \pm 16$ & $1044 \pm 8$ \\
Elongation to fracture A in \% & $66 \pm 3$ & $64 \pm 8$ & $66 \pm 2$ & $67 \pm 7$ \\
Hardness HV10 & $260 \pm 5$ & $270 \pm 4$ & $271 \pm 9$ & $278 \pm 13$ \\
\hline & $\mathbf{4 0 \%}$ Cold worked & \multicolumn{3}{c}{$\mathbf{3 5 \%}$ Cold worked } \\
Yield strength $\mathrm{R}_{\mathrm{p} 0.2 \text { in } \mathrm{MPa}}$ & $1890 \pm 15$ & $1343 \pm 12$ & $1425 \pm 7$ & $1500 \pm 13$ \\
Tensile strength $\mathrm{R}_{\mathrm{m}}$ in MPa & $1901 \pm 9$ & $1374 \pm 11$ & $1432 \pm 9$ & $1520 \pm 5$ \\
Elongation to fracture A in \% & $18 \pm 7$ & $45 \pm 9$ & $43 \pm 4$ & $34 \pm 2$ \\
Hardness HV10 & $510 \pm 9$ & $464 \pm 8$ & $472 \pm 7$ & $475 \pm 12$ \\
\hline
\end{tabular}

The $R_{\mathrm{p} 0.2}, R_{\mathrm{m}}$, and $A$ are close for all steels after solution annealing. In order to compare similar cold-worked states, the 1.4452 was also strained to $35 \%$ and afterwards revealed a $R_{p 0.2}$ of $1370 \mathrm{MPa}$, $R_{m}$ of $1393 \mathrm{MPa}$, and $A$ of $41 \%$. Thus, while $R_{p 0.2}$ and $R_{m}$ slightly increase with $C+N$, a decreases in relation to the sum of interstitials after $35 \%$ cold work.

\subsection{Fatigue Properties}

The fatigue properties in Table 3 reveal a somewhat inconsistent picture. For the solution annealed states, the fatigue limit shows some relation to the sum of interstitials. Still, it appeared that above a 1 weight- $\%$ of $\mathrm{C}+\mathrm{N}$, it might even decrease slightly [14]. It is more interesting to notice that despite the distinct gain of $\mathrm{R}_{\mathrm{p} 0.2}$ by work hardening (Table 2, Figure 2), the fatigue limit hardly follows that trend (Table 3, Figure 2). The most distinct increase can be noticed for CN0.85 from 320 to $390 \mathrm{MPa}$ after $30 \%$ 
cold work, while the AHNS 1.4452 reaches $382 \mathrm{MPa}$. For the CN0.96, there is a decrease of $\sigma_{\mathrm{D}}$ from 390 to $360 \mathrm{MPa}$ after $30 \%$ cold work, while $\sigma_{\mathrm{D}}$ of $\mathrm{CN} 1.07$ stays about the same.

Table 3. Fatigue properties at $\mathrm{N}=2 \times 10^{6}$ of the investigated steels after solution annealing and after uniaxial cold-working.

\begin{tabular}{|c|c|c|c|c|}
\hline Steel & 1.4452 & CN0.85 & CN0.96 & CN1.07 \\
\hline & \multicolumn{4}{|c|}{ Solution annealed } \\
\hline Total strain amplitude $\varepsilon_{\mathrm{a}, \mathrm{t}}$ in $\%$ at fatigue limit & 0.16 & 0.17 & 0.2 & 0.16 \\
\hline Fatigue limit $\sigma_{\mathrm{D}}$ in $\mathrm{MPa}$ & 320 & 320 & 390 & 313 \\
\hline $\mathrm{R}^{2}$ of $\sigma_{\mathrm{D}}$ & 0.98 & 0.96 & 0.99 & 0.99 \\
\hline Cyclic strain hardening exponent $\mathrm{n}^{\prime}$ in $\mathrm{MPa}$ & 0.126 & 0.156 & 0.186 & 0.206 \\
\hline \multirow[t]{2}{*}{ Cyclic strength coefficient $\mathrm{K}^{\prime}$ in $\mathrm{MPa}$} & 1.041 & 1.093 & 1.258 & 1.375 \\
\hline & $40 \%$ Cold worked & \multicolumn{3}{|c|}{$35 \%$ Cold worked } \\
\hline Total strain amplitude $\varepsilon_{\mathrm{a}, \mathrm{t}}$ in $\%$ at fatigue limit & 0.19 & 0.2 & 0.18 & 0.16 \\
\hline Fatigue limit $\sigma_{\mathrm{D}}$ in $\mathrm{MPa}$ & 382 & 390 & 360 & 306 \\
\hline Cyclic strength coefficient $\mathrm{K}^{\prime}$ in $\mathrm{MPa}$ & 1.382 & 1.111 & 1.769 & 2.539 \\
\hline
\end{tabular}

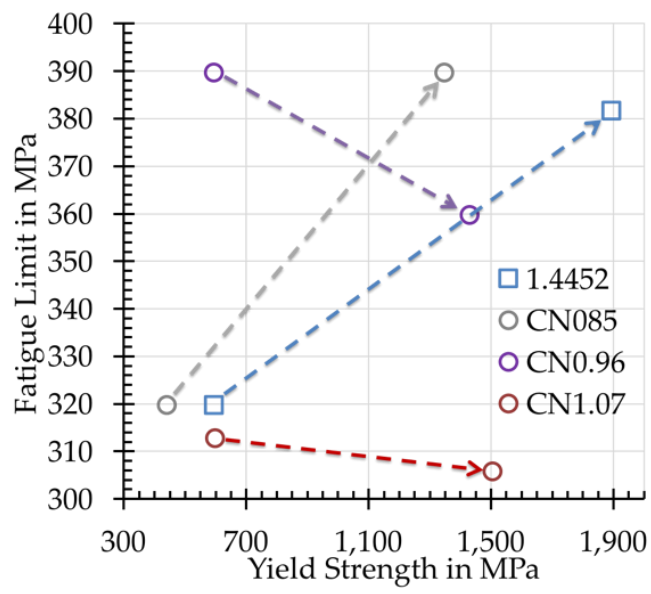

Figure 2. Fatigue limits and yield strengths of steels after solution annealing $\left(\mathrm{R}_{\mathrm{p} 0.2}<650 \mathrm{MPa}\right)$ and after cold-working $\left(\mathrm{R}_{\mathrm{p} 0.2}>1300 \mathrm{MPa}\right)$.

\subsection{Microstructure}

Microstructure of Cold-Worked Steels before and after Fatigue Testing

The microstructures of the steels depict grain boundaries and some non-metallic inclusions, while the twins have been mostly generated by cold working. If one compares these cold-worked microstructures before and after fatigue testing at the endurance level, there is hardly any difference to be noticed (Figure 3) by light-microscopy.

In order to gain better information, EBSD analyses were carried out (Figure 4). Obviously, after cold-working, any strain-induced phase transformations of the austenite into $\varepsilon$-martensite can be ruled out [29]. Thus, TRIP (transformation induced plasticity) effects did not influence the fatigue behavior.

Still, there is very little difference between the deformation appearances before and after fatigue testing at the endurance limit. But, by the fading, as well as changing colors, inside grains, it is discernable that after cold work, a marked dislocation activity has already taken place. Point-to-origin and point to-point analyses revealed mostly $60^{\circ}$ for deformation twins only inside the 111-grains. 
The misorientation inside the other grains did not exceed $6^{\circ}$, being characteristic for dislocation accumulation, as well as for pile-ups or bundles. Subgrains could not be identified [29].

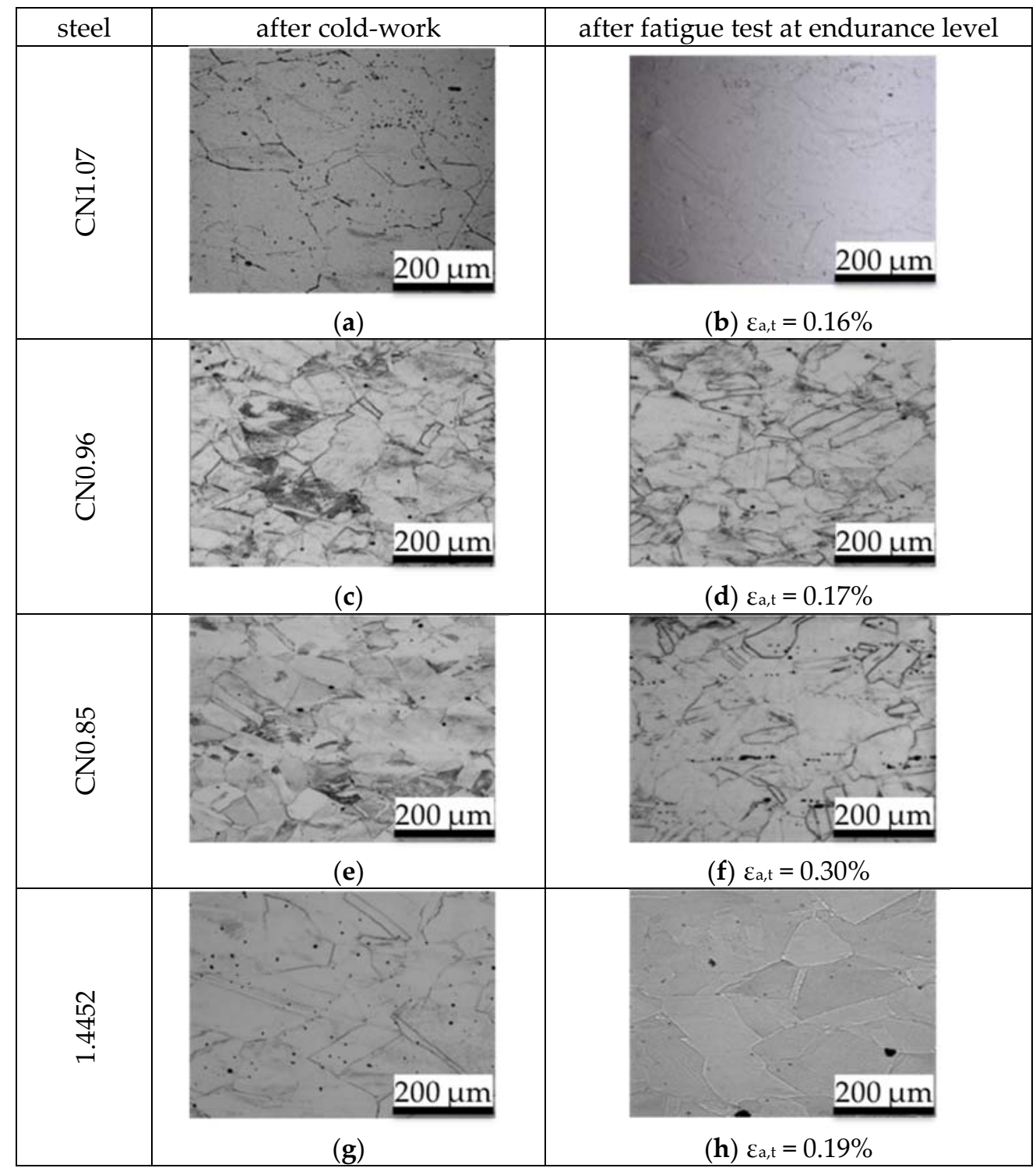

Figure 3. Microstructures of steels after cold-work and after fatigue tests, with information about the total strain amplitude applied at endurance level for $\mathrm{N} \geq 2 \times 10^{6}$. (a,b) CN 1.07; (c,d) CN 0.96; $(\mathbf{e}, \mathbf{f})$ CN $0.85 ;(g, h) 1.4452$. 


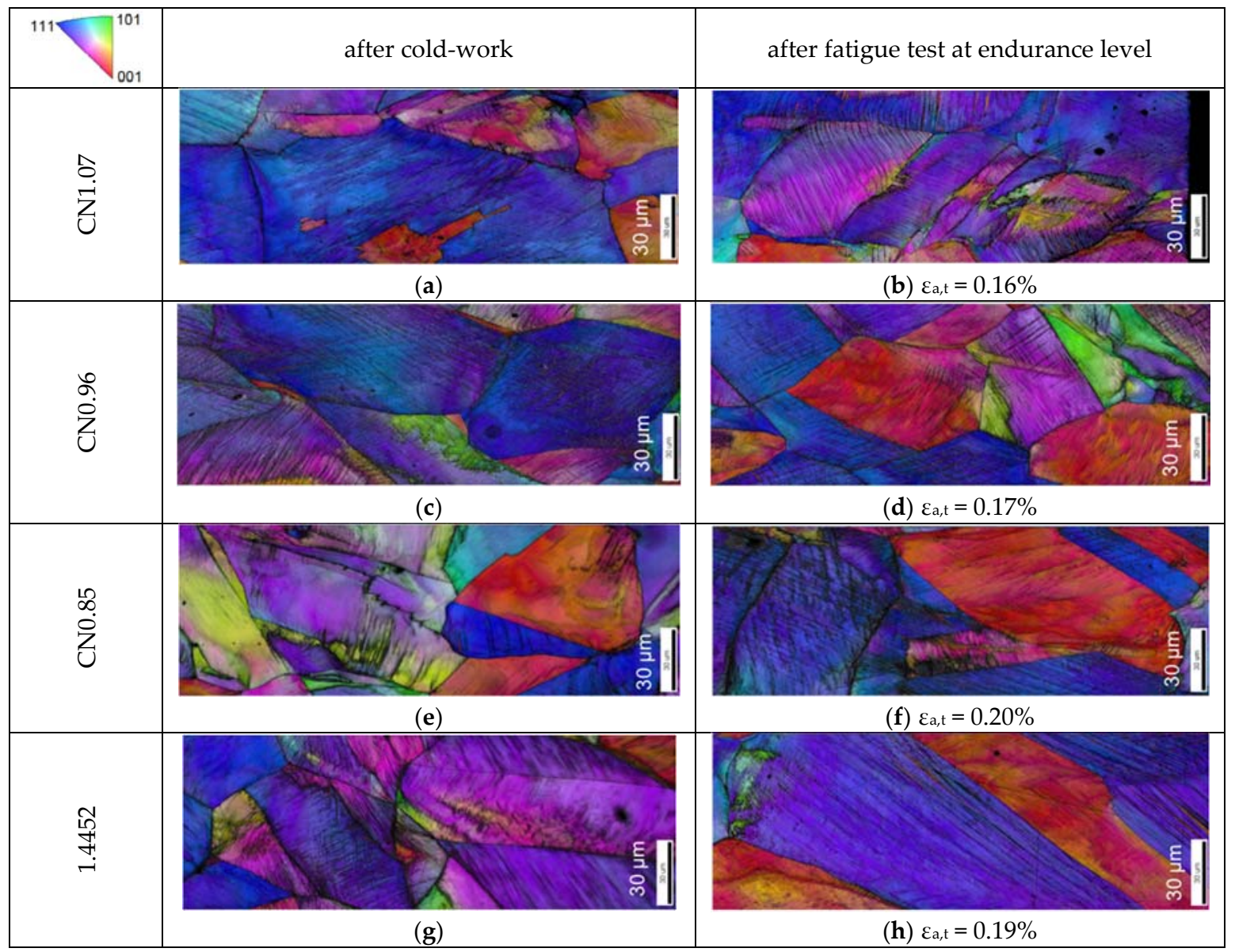

Figure 4. EBSD inverse pole figure and image quality contrast of steels after cold-work and after fatigue tests, with information about the total strain amplitude applied at the endurance level for $\mathrm{N} \geq 2 \times 10^{6}$. (a,b) CN1.07; (c,d) CN0.96; (e,f) CN 0.85; (g,h) 1.4452.

\section{Discussion}

According to empirical relations and thick-thumb rules for wrought austenitic steels, $\sigma_{\mathrm{D}}$ should be at minimum 0.5 times of $R_{p 0.2}$ (Figure 5) [10,12-14,17,30-32]. Thus, it is interesting to notice that all solution annealed steels $\left(\mathrm{R}_{\mathrm{p} 0.2}<700 \mathrm{MPa}\right)$ nearly fulfill this empirical criterion, while for the cold-worked steels, only 1.4441 and CN0.96 do so up to a yield strength of $1100 \mathrm{MPa}$ (Figure 5).

Beside the different testing methods used (rotating bending, axial fatigue test), it appears that increasing the yield strength by cold-work leads to a gradual decrease of the fatigue limit. For the CrNiC-, as well as $\mathrm{CrMnNiC}$-steels, it has been shown that during-cold work, beside dislocations. additional twins evolve, of which the density increases with the degree of deformation. Inside such arrays of twins, defect-poor volumes exist, which become smaller by increasing predeformation. As a result, smaller dislocation cells of a higher density are generated under finite-life fatigue and, therefore, render an increase of the stress amplitude [12,33]. Thus, for $\mathrm{CrNiC}$-steels, planar sliding prevails under cold-work, while under fatigue conditions, wavy slip is characteristic. For the CN0.96, this is different, because it solely shows planar slip under cold-work and under any fatigue loading [34]. But, $\sigma_{\mathrm{D}}$ increases for such CrMnCN-steel after 20\% cold-work, as well resulting in a $\mathrm{R}_{\mathrm{p} 0.2}$ of $1092 \mathrm{MPa}$. However, after $35 \%$ of cold-work and an even higher $\mathrm{R}_{\mathrm{p} 0.2}, \sigma_{\mathrm{D}}$ decreases. 


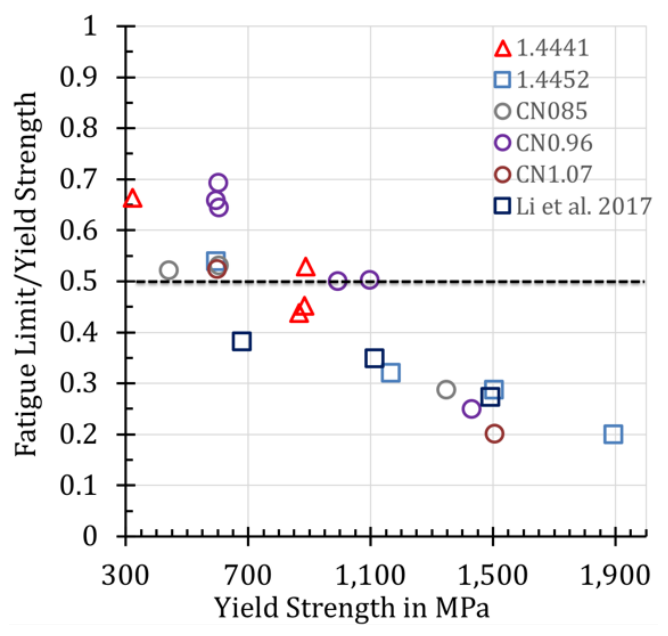

Figure 5. The fatigue limit in relation to the yield strength of solution-annealed and cold-worked austenitic steels. Own data and those of [10,12-14,17,30-32].

\subsection{Materials Science Aspects}

Most fatigue papers concentrate on finite life tests as they show dislocation activities galore. But here, the infinite life is aimed for and, therefore, no distinct differences as to the microstructures before and after fatigue tests can be shown [13,35]. One additional aspect to be regarded comes from the fact that at the fatigue limit, $\mathrm{CrNiC}$ and $\mathrm{CrNiCN}$ steels also slide only planarly, even though they are known for wavy slip in the finite life regime above a certain $\varepsilon_{\mathrm{a}, \mathrm{t}}$ [12]. The microstructure of wavy sliding metals like $\mathrm{Cu}$ and some of its alloys, as well as $\mathrm{CrNiC}$ or $\mathrm{N}$-free $\mathrm{CrMnC}$ steels, are characterized by veins, persistent sliding-bands (PSB), and dislocation cells [33,36]. It also became clear that the addition of N somehow hinders-but might not fully avoid — the development of such wavy characteristics [2]. For the infinite life regime, any different behavior so far could only be hypothesized on the basis of the tendency of alloys to change the sliding characteristics, if loaded at higher stress or strain amplitudes. Thus, the most important feature is the distinct localization of deformation characteristics, if $\mathrm{N}$ is added and Ni is substituted by Mn [32,37]. Shao presented a model that showed some sort of double slip capabilities of a solution annealed $\mathrm{CrMnN}$-steel with 0.63 weight- $\% \mathrm{~N}$ under finite life conditions. Following [38], he pointed out the importance of short-range order (SRO) effects that in such steels are likely brought about by strong $\mathrm{Cr}-\mathrm{N}$ interactions. On the basis of TEM analyses, he concluded that for such steels, planar slip leads to strain localization. This renders a bi-linear Basquin behavior that differs between the finite- and the infinite-life regime. But, this would also be true for CrNiCand $\mathrm{CrNiCN}$-steels, which as confirmed by our own results, show the same differences depending on $\varepsilon_{\mathrm{a}, \mathrm{t}}[14,39]$. Still and in contrast to $\mathrm{N}$-free $\mathrm{CrNiC}$-steels, he points out a special microstructural feature that appears to be unique for metals showing only planar slip at all $\varepsilon_{\mathrm{a}, \mathrm{t}}$ : Persistant Lueders-bands (PLB). These are known as a form of cyclic strain localization typical of low stacking fault energy (SFE) face-centered-cubic metals [40,41].

In order to verify this, we analyzed the microstructures by TEM after the fatigue tests in the finite life regime at $\varepsilon_{\mathrm{a}, \mathrm{t}}=1.5 \%$, as it should generate distinct dislocation activities. As a result, Figure 6 shows PLBs within the microstructure of CN0.85 similar to those of [32].

Thus, beside twins, dislocation bundles, and sliding bands, the PLBs appear to govern the fatigue behavior. It must be mentioned that quite a few of the TEM samples also showed microcracks at such PLBs and at dense sliding bands. But, these could also stem from foil preparation and cannot be taken into consideration for an early crack initiation. Still, the modulus of the fatigue samples dropped from 200 to $160 \mathrm{GPa}$ at $\varepsilon_{\mathrm{a}, \mathrm{t}}$ above the endurance limit [29]. Such early crack initiation is quite likely due to extreme localization of sliding and PLBs would certainly support this. The distinctly slower stable crack propagation rate of such solely planar sliding steels, as reported in [42], still allows for sufficient 
fatigue properties in relation to life time, but obviously not for higher fatigue limits by cold working above an $R_{\mathrm{p} 0.2}$ of $1100 \mathrm{MPa}$.

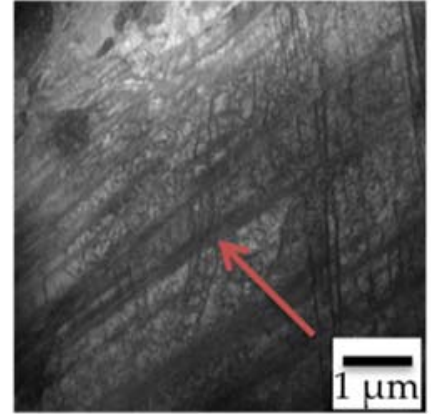

(a)

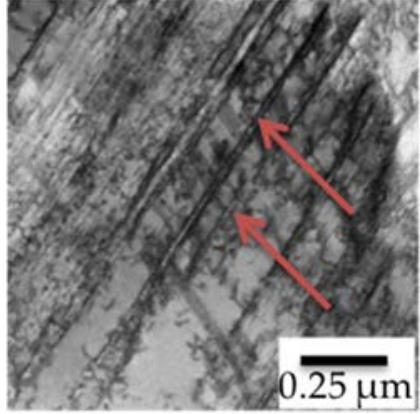

(b)

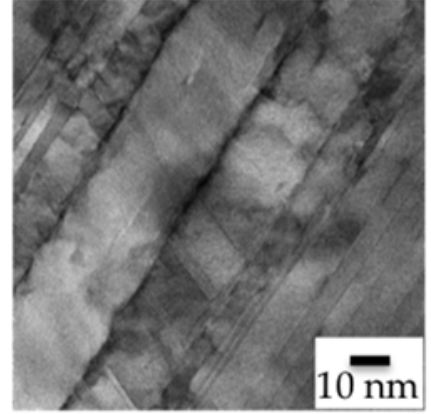

(c)

Figure 6. TEM micrographs of CN0.85 after cold-work and fatigue test at $\varepsilon_{\mathrm{a}, \mathrm{t}}=1.5 \%$. (a) high density of sliding bands; (b) persistent Lueders bands; (c) details of (b).

\subsection{Materials Engineering Aspects}

Beside the open question about the SRO-effects that in combination with SFE obviously rule this peculiar behavior, any application of such steels would require a certain degree of robustness against cyclic overloading. In general, this can be described by sufficient ductility in combination with strain-hardening capability. Certainly, AHNS- and AHIS-steels would provide this under monotonic loading, as already depicted by the integral under stress-strain curves [32,43]. For cyclic loading, [32] proposed a criterion for the capacity to dissipate cyclic plastic work by twinning- (TWIP) or strain-induced phase transformation (TRIP). Such "robust" behavior could, therefore, be described by a minimum of the cyclic strain hardening exponent $n^{\prime}$. In [39], we showed that after solution annealing, $\sigma_{\mathrm{D}}$ is mainly governed by the sum of $\mathrm{C}+\mathrm{N}$, while $\mathrm{n}^{\prime}$ can additionally be controlled by an optimized N/Ni-ratio. Due to the fact that Ni counteracts the positive effect of $\mathrm{N}$, this ratio was found to work well between 1 and 10. Thus, this relates to very small amounts of $\mathrm{Ni}$ that must be adjusted in relation to 0.6 to 0.9 weight-\% of N. It should be mentioned here that for TRIP-steel types, this criterion neither showed any relation to $\mathrm{C}+\mathrm{N}$ nor to $\mathrm{N} / \mathrm{Ni}$. Now that at this point of data $\sigma_{\mathrm{D}}$ cannot be improved, it appears interesting to explore whether cold working has a positive or a detrimental effect on such robustness. Figure 7 displays $n$ ' for the solution annealed and the cold-worked states in comparison.

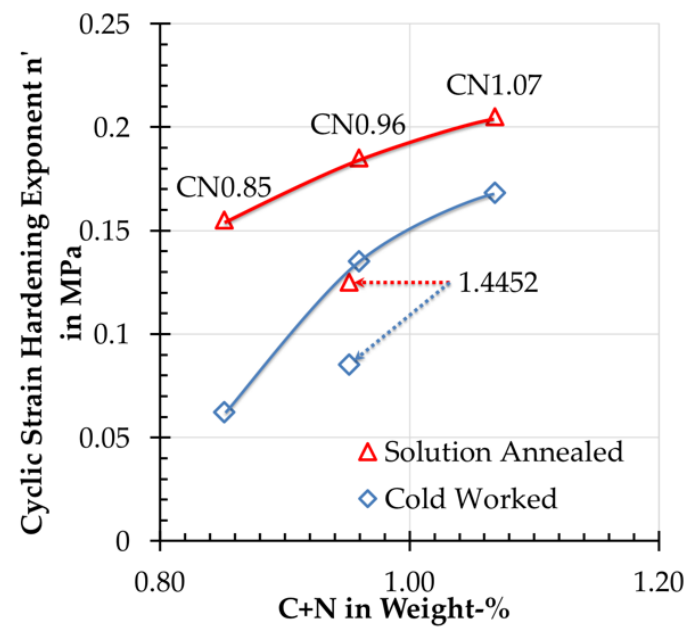

Figure 7. Cyclic strain hardening exponent $n^{\prime}$ in relation to the sum of $\mathrm{C}+\mathrm{N}$. 
Obviously, n' increases for the cold-worked CN-type (AHIS) of steels with $\mathrm{C}+\mathrm{N}$ (Figure 7, red line), as it does for the solution annealed states (blue line). The AHNS-type of steel does not fit into this tendency (Figure 7, pointed arrows). Thus, the effect of $\mathrm{N}$ as the main interstitially dissolved element has a different influence on the fatigue behavior compared to the combined effect of $\mathrm{C}+\mathrm{N}$. It must be mentioned here that this is presumably based on the differing SRO-effects of $\mathrm{C}, \mathrm{N}$, or $\mathrm{C}+\mathrm{N}$, which are still under investigation and, therefore, not fully understood. But, all cold worked states show smaller $\mathrm{n}^{\prime}$-values compared to the solution annealed ones. Thus, if we follow the "robustness" criterion of [32], it becomes clear that cold-working has a positive effect on the cyclic robustness.

From our data and those of $[30,34]$ we have to understand that for $\mathrm{CrMnCN}$-steels, there is evidently a certain optimal defect density generated by cold-work that would allow $\sigma_{D}$ to follow $0.5 \times \mathrm{R}_{\mathrm{p} 0.2}$. Thus, the $35 \%$ that we used might have been too high in comparison to Riedner's $20 \%$. It also appeared interesting that we were not able to find any published paper on the infinite-life fatigue limit of bulk cold-worked Ni-free or -alloyed austenitic steels with $R_{p 0.2}>1100 \mathrm{MPa}$. Thus, it remains unclear whether the $1100 \mathrm{MPa}$ limit is accidental or based on a certain defect type and/or density. Further research is therefore necessary in order to be able to explain this behavior and find the optimum degree of cold-work, sum, and ratio of $\mathrm{C}$ and $\mathrm{N}$ in CrMnCN-steels, as well as the best $\mathrm{N} / \mathrm{Ni}$-ratio, in order to gain higher infinite-life fatigue limits.

Author Contributions: S.G. carried out the tensile and fatigue experiments, as well as the metallographic analyses; A.F. wrote the paper.

Funding: There was no funding by any public or private entity. This work is solely based on scientific interest.

Acknowledgments: The authors would like to thank D. Valenta, R. Giese, and F. Ebert for support during the fatigue experiments. We are also in debt to B. Gleising of ICAN, University of Duisburg-Essen, Germany and W. Dudzinski of TU-Wroclaw, Poland for TEM analyses.

Conflicts of Interest: The authors declare no conflict of interest.

\section{References}

1. Gavriljuk, V.G.; Berns, H. High Nitrogen Steels: Structure, Properties, Manufacture, Applications; Springer: Berlin, Germany, 1999.

2. Vogt, J.B.; Degallaix, S.; Foct, J. Low cycle fatigue life enhancement of $316 \mathrm{~L}$ stainless steel by nitrogen alloying. Int. J. Fatigue 1984, 6, 211-215. [CrossRef]

3. Degallaix, S.; Degallaix, G.; Foct, J. Influence of Nitrogen Solutes and Precipitates on Low Cycle Fatigue of $316 l$ Stainless Steels; Solomon, H.D., Halford, G.R., Kaisand, L.P., Leis, B.N., Eds.; ASTM International: Bolton Landing, NY, USA, 1987; pp. 798-811.

4. Tikhovskiy, I. Quasistatic, cyclic and electrochemical behavior of a high nitrogen austenitic stainless steel according to ISO 5832-9 in the solution annealed state. Unpublished work. 2003.

5. Tikhovskiy, I.; Fischer, A.; Weiß, S. Cyclic deformation behaviour of austenitic crmnmon steel in solution annealed and cold worked states. In Proceedings of the HNS-Conference, Ostende, Belgium, 19-22 September 2014; GRIPS-Media GmbH: Bad Harzburg, Germany, 2004; pp. 259-263.

6. Berns, H.; Gavriljuk, V.G.; Riedner, S.; Tyshchenko, A. High strength stainless austenitic crmncn steels—Part I: Alloy design and properties. Steel Res. Int. 2007, 78, 714-719. [CrossRef]

7. Gavriljuk, V.G.; Razumov, O.; Petrov, Y.; Surzhenko, I.; Berns, H. High strength stainless austenitic crmncn steels-Part II: Structural changes by repeated impacts. Steel Res. Int. 2007, 78, 720-723. [CrossRef]

8. Shanina, B.D.; Gavriljuk, V.G.; Berns, H. High strength stainless austenitic crmnn steels-Part III: Electronic properties. Steel Res. Int. 2007, 78, 724-728. [CrossRef]

9. Berns, H.; Gavriljuk, V.; Riedner, S. High Interstitial Stainless Austenitic Steels; Springer Science \& Business Media: Berlin, Germany, 2012.

10. Orita, K.; Ikeda, Y.; Iwadate, T.; Ishizaka, J. Development and production of $18 \mathrm{Mn}-18 \mathrm{Cr}$ non-magnetic retaining ring with high yield strength. ISIJ Int. 1990, 30, 587-593. [CrossRef]

11. Raman, S.G.S.; Padmanabhan, K.A. Effect of prior cold work on the room-temperature low-cycle fatigue behaviour of AISI 304LN stainless steel. Int. J. Fatigue 1996, 18, 71-79. [CrossRef] 
12. Göbbeler, P. Untersuchungen Zum Ermüdungsverhalten des Kaltumgeformten Austenitischen Implantatwerkstoffes X2 CrNiMo 18-15-3-1.4441; VDI Verlag: Düsseldorf, Germany, 1998; ISBN 3-18-351305-6.

13. Schymura, M.; Fischer, A. Metallurgical aspects on the fatigue of solution-annealed austenitic high interstitial steels. Int. J. Fatigue 2014, 61, 1-9. [CrossRef]

14. Schymura, M.; Fischer, A. Fatigue of austenitic high interstitial steels-The role of $\mathrm{N}$ and C. In Proceedings of the 11th International Fatigue Congress, FATIGUE 2014, Melbourne, Australia, 2-7 March 2014; Trans Tech Publications: Melbourne, Australia, 2014; Volumes 891-892, pp. 403-409.

15. Fischer, A.; Weiss, S.; Wimmer, M.A. The tribological difference between biomedical steels and cocrmo-alloys. J. Mech. Behav. Biomed. Mater. 2012, 1, 50-62. [CrossRef] [PubMed]

16. Gavriljuk, V.G.; Shanina, B.D.; Berns, H. A physical concept for alloying steels with carbon + nitrogen. Mater. Sci. Eng. A 2008, 481-482, 707-712. [CrossRef]

17. Berns, H.; Gavriljuk, V.G.; Nabiran, N.; Petrov, Y.N.; Riedner, S.; Trophimova, L.N. Fatigue and structural changes of high interstitial stainless austenitic steels. Steel Res. Int. 2010, 81, 299-307. [CrossRef]

18. Schramm, R.E.; Reed, R.P. Stacking fault energies of seven commercial austenitic stainless steels. Metall. Trans. A 1975, 6, 1345-1351. [CrossRef]

19. Remy, L. Temperature variation of the intrinsic stacking fault energy of a high manganese austenitic steel. Acta Metall. 1977, 25, 173-179. [CrossRef]

20. Stoltz, R.E.; Vander Sande, J.B. The effect of nitrogen on stacking fault energy of Fe-Ni-Cr-Mn steels. Metall. Trans. A 1980, 11, 1033-1037. [CrossRef]

21. Gavriljuk, V.; Petrov, Y.; Shanina, B. Effect of nitrogen on the electron structure and stacking fault energy in austenitic steels. Scr. Mater. 2006, 55, 537-540. [CrossRef]

22. Mujica, L.; Weber, S.; Theisen, W. The stacking fault energy and its dependence on the interstitial content in various austenitic steels. Mater. Sci. Forum 2012, 706-709, 2193-2198. [CrossRef]

23. Das, A. Revisiting stacking fault energy of steels. Metall. Mater. Trans. 2016, 47, 748-768. [CrossRef]

24. Wang, Z. Cyclic deformation response of planar-slip materials and a new criterion for the wavy-to-planar-slip transition. Philos. Mag. 2004, 84, 351-379. [CrossRef]

25. Murayama, M.; Hono, K.; Hirukawa, H.; Ohmura, T.; Matsuoka, S. The combined effect of molybdenum and nitrogen on the fatigued microstructure of 316 type austenitic stainless steel. Scr. Mater. 1999, 41, 467-473. [CrossRef]

26. Tikhovskiy, I. Untersuchungen zum Zyklischen Verformungsverhalten des Hochstickstofflegierten Austenitischen Stahles X13CrMnMoN 18-14-3(1.4452); Materials Science and Engineering; s.a. Fortschr.-Ber. VDI Reihe 5: Grund-und Werkstoffe/Kunststoffe, Nr. 717; VDI Verlag: Düsseldorf, Germany, 2005; ISBN 3-18-371705-0.

27. Mitchell, M.R. Fundamentals of modern fatigue analysis for design. In Science Seminar, 10 Materials Science Division of Asm; ASM Materials: St. Louis, MO, USA, 1978; pp. 14-15.

28. Nieslony, A.; el Dsoki, C.; Kaufmann, H.; Krug, P. New method for evaluation of the Manson-Coffin-Basquin and Ramberg-Osgood equations with respect to compatibility. Int. J. Fatigue 2008, 30, 1967-1977. [CrossRef]

29. Güler, S. Einfluss der Kaltverformung auf das Ermüdungsverhalten von Austenitischen Hochinterstitiell Legierten Stählen. Ph.D. Thesis, University of Duisburg-Essen, Duisburg, Germany, 2017.

30. Tikhovskiy, I.; Weiß, S.; Fischer, A. Cyclic deformation behaviour of austenitic crmnmon steel in solution annealed and cold-worked states. Steel Grips 2004, 2, 259-263.

31. Li, J.; Yang, Y.; Ren, Y.; Dong, J.; Yang, K. Effect of cold deformation on corrosion fatigue behavior of nickel-free high nitogen austenitic stainless steel for coronary stent application. J. Mater. Sci. Technol. 2017, 34, 660-665. [CrossRef]

32. Shao, C.W.; Zhang, P.; Liu, R.; Zhang, Z.J.; Pang, J.C.; Zhang, Z.F. Low-cycle and extremely-low-cycle fatigue behaviors of high-mn austenitic trip/twip alloys: Property evaluation, damage mechanisms and life prediction. Acta Mater. 2016, 103, 781-795. [CrossRef]

33. Lambers, H.G.; Rüsing, C.J.; Niendorf, T.; Geissler, D.; Freudenberger, J.; Maier, H.J. On the low-cycle fatigue response of pre-strained austenitic $\mathrm{Fe}_{61} \mathrm{Mn}_{24} \mathrm{Ni}_{6.5} \mathrm{Cr} 8.5$ alloy showing twip effect. Int. J. Fatigue 2012, 40, 51-60. [CrossRef]

34. Riedner, S. Höchstfeste Nichtrostende Austenitische Crmn-Stähle Mit $(C+N)$; Ruhr Universität Bochum: Bochum, Germany, 2010.

35. Güler, S.; Schymura, M.; Fischer, A. Austenitic high interstitial steels vs. Cocrmo-Comparison of fatigue behavior. Int. J. Fatigue 2015, 75, 145-152. [CrossRef] 
36. Polak, J.; Obrtlik, K.; Hajek, M. Cyclic plasticity in type 3161 austenitic stainless steel. Fatigue Fract. Eng. Mater. Struct. 1994, 17, 773-782. [CrossRef]

37. Shao, C.W.; Zhang, P.; Liu, R.; Zhang, Z.J.; Pang, J.C.; Duan, Q.Q.; Zhang, Z.F. A remarkable improvement of low-cycle fatigue resistance of high-mn austenitic twip alloys with similar tensile properties: Importance of slip mode. Acta Mater. 2016, 118, 196-212. [CrossRef]

38. Gerold, V.; Karnthaler, H.P. On the origin of planar slip in fcc Alloys. Acta Metall. 1989, 37, $2177-2183$. [CrossRef]

39. Güler, S.; Schymura, M.; Fischer, A.; Droste, M.; Biermann, H. The influence of the nitrogen/nickel-ratio on the cyclic behavior of austenitic high strength steels with twinning-induced plasticity and transformation-induced plasticity effects. Materialwissenschaft und Werkstofftechnik 2018, 49, 61-72. [CrossRef]

40. Buchinger, L.; Cheng, A.S.; Stanzl, S.; Laird, C. The cyclic stress-strain response and dislocation structures of Cu-16 at. \%Al alloy III: Single crystals fatigued at low strain amplitudes. Mater. Sci. Eng. 1986, 80, 155-167. [CrossRef]

41. Christ, H.J. Wechselverformung von Metallen; Springer: Berlin, Germany, 1991.

42. Schymura, M.; Stegemann, R.; Fischer, A. Crack propagation behavior of solution annealed austenitic high interstitial steels. Int. J. Fatigue 2015, 79, 25-35. [CrossRef]

43. Gavriljuk, V.G.; Tyshchenko, A.I.; Bliznuk, V.V.; Yakovleva, I.L.; Riedner, S.; Berns, H. Cold work hardening of high-strength austenitic steels. Steel Res. Int. 2008, 79, 413-422. [CrossRef]

(C) 2018 by the authors. Licensee MDPI, Basel, Switzerland. This article is an open access article distributed under the terms and conditions of the Creative Commons Attribution (CC BY) license (http://creativecommons.org/licenses/by/4.0/). 